\title{
IS THE NIGERIAN STOCK MARKET EFFICIENT? PRE AND POST 2007-2009 MELTDOWN ANALYSIS
}

\section{Kamaldeen Ibraheem Nageri*}

Department of Banking and Finance, Al-Hikmah University, Ilorin, Nigeria

E-mail: nagerisuccess2000@yahoo.co.uk

\section{Rihanat Idowu Abdulkadir}

Department of Finance, University of Ilorin, Ilorin, Nigeria

\section{(Received: February 2019; Accepted: April 2019; Published: August 2019)}

\begin{abstract}
Efficient market hypothesis asserts movements in asset prices are due to significant changes in information. The financial crisis of 2007-2009 originated from subprime mortgages in the United States and affected African countries through local stock markets. This study evaluates the Nigerian stock market efficiency in the pre and post financial meltdown of 2007-2009. GARCH models under three error distributional assumptions were used. The data covers January 2010 to December 2016 divided into pre and post meltdown. Findings indicate that in the pre and post meltdown, the Nigerian stock market is inefficient in the weak form while using the meltdown as event window, the market is efficient in the semi-strong form. It was recommended that prompt release of financial information by quoted firms should be on-line real time and mandatory to discourage rumour and speculative activities. Authority should not only spell out punishments but should be strict and firm about it.
\end{abstract}

Keywords: Market efficiency, Stock market, Meltdown, GARCH.

JEL Codes: C58, G01, G14

\section{Introduction}

Bubbles or booms in asset price have spawned significant attention because when it ultimately turns into burst, it led to disorder in consumer behaviour and decision, financial markets, businesses and the economy as a whole (Evanoff, Kaufman \& Malliaris, 2012; Claessens \& Kose, 2013; Gust, 2004). The efficient market hypothesis asserts that unexpected movements in asset prices are a result of

\footnotetext{
* Corresponding author: Kamaldeen Ibraheem Nageri. E-mail: nagerisuccess2000@yahoo.co.uk

Copyright (C) 2019 The Author(s). Published by VGWU Press

This is an Open Access article distributed under the terms of the Creative Commons Attribution License - Non Commercial - NoDerivs License (http://creativecommons.org/licenses/by-nc-nd/3.0/) which permits unrestricted $\underline{\text { use, distribution, and reproduction in any medium, provided the original author and source are credited. }}$
} 
Nageri, K.I., Abdulkadir, R.I., (2019)

Is the nigerian stock market efficient? Pre and post 2007-2009 meltdown analysis

significant changes in information about fundamentals. Therefore, actual and fundamental prices are always the same, and bubbles cannot exist unless they are motivated by irrational behavior or market stringencies (Evanoff, Kaufman, \& Malliaris, 2012). The financial crisis of 2008-2009 originated as a result of the subprime mortgages in the United States. It led to the liquidation of many banking and non-banking institutions, and investors' loss of confidence in the credit markets worldwide (Farhi \& Cintra, 2009 and Prates \& Cintra, 2010).

The crisis spread to developing countries but it was originally anticipated that the impact on Africa would be insignificant because of the low level of Africa financial market integration into global financial markets, but the impact was very serious on Africa (Kaberuka, 2009; Osakwe, 2010). The crisis affected African countries through its impact on local stock markets and led to an increase in stock market volatility. From December 2007 and January 2010 the Nigerian, Kenyan, Zambian and Egyptian stock market index declined by 62\%, 35\%, 27\% and 30\% respectively. Between 2007 and 2008, the Namibian, Mauritius and Egyptian stock market lost about 55\%, 41\% and 36\% of their market value respectively (Osakwe, 2010).

According to efficient stock market hypothesis, changes in stock prices are impossible to forecast from available public information but stock price can only move as a result news/information that changes the market's perception of a firm's asset value. The critics of the efficient market hypothesis argued that it is better as an academic explanation of investor's rational expectation than might be assumed in practice.

Bailey, Kumar and Ng, (2011); Baker and Nofsinger, (2010); Fox, (2009); Shefrin, (2007); Shiller, (2000); Simon, (1957); Thaler, (1993 \& 2005) stressed that shareholders are not always rational and that stock prices are not always informational efficient because of psychological perception (behavioural human tendency i.e irrationality) of investors and economic outlook (small firm and value effects, excess volatility and overreaction and seasonality). In response, the advocate (Fama, 1965; Samuelson, 1965) of the efficient stock market hypothesis argued that even if the stock price is not exactly informational efficient, it is actually close to it (Malkiel, 2003).

Therefore, the extent of efficiency or inefficiency of the stock market is yet to be convincingly determined. Meanwhile, the Nigerian stock market experienced growth in market capitalization and All Share Index from 2001 till the second quarter of 2008. The market experienced serious decline in its indicators afterwards, due to the negative impact of the financial meltdown of 2008-2009.

Studies prior to the financial meltdown of 2007-2009 tested the form of efficiency exhibited by the Nigerian stock market (Adelegan, 2003 \& 2004; Afego, 2012; Agwuegbo, Adewole \& Maduegbuna, 2010; Ajao \& Osayuwu, 2012; Ayadi, 1984; 
Nageri, K.I., Abdulkadir, R.I., (2019)

Is the nigerian stock market efficient? Pre and post 2007-2009 meltdown analysis

Azeez \& Sulaiman, 2012; Ekechi, 2002; Emenike, 2008; Inegbedion, 2009; Nwosa \& Oseni, 2011; Okpara, 2010; Olowe, 1999; Oludoyi, 1998; Vitali \& Mollah, 2010; Rapuluchukwu, 2010; Samuels \& Yacout, 1981) indicated that the Nigerian stock market efficiency is inconclusive with inconsistent results.

During the financial crisis, studies by Ajibola, Prince and Lenee (2014), Gimba (2012), Isenah and Olubusoye (2014), Obayagbona and Igbinosa (2015) and Osazevbaru (2014) showed that Nigerian stock market is not efficient in the weak form. Nwidobie (2014 \& 2015), Nwosa and Oseni (2011), Yadirichukwu and Ogochukwu (2014), Oke and Azeez (2012) used data covering periods before and during the crises, provides conflicting results of the Nigerian stock market efficiency.

Therefore, the objective of this study is to evaluate the Nigerian stock market efficiency in the pre and post financial meltdown of 2007-2009. Thus, this study is the pioneer work to identify the gap in the literature and the need to evaluate the Nigerian stock market efficiency before and after the meltdown is long overdue.

This research is significance because the 2007-2009 meltdown was found to have impacted the Nigerian stock market (Arunma, 2010; Ayuba, 2011; Njiforti, 2015; Ujunwa, Salami \& Umar, 2011) this is because the meltdown has information which affect the prices of share on the Nigerian stock market. The policy response of the Nigerian stock market regulators to the impact of the meltdown on the stock market also propelled the need for this study. This study will reveal the difference or otherwise in the efficiency of the Nigerian stock market with regards to the policy responses and measures in the market regarding the meltdown of 20072009.

The scope of this research is the evaluation of stock market efficiency, making Nigeria stock exchange the reference point during the pre and post financial meltdown. The weekly All Share Index (ASI) between the periods of January 2001 till December 2016 was used. The data was terminated in the 2016 in order to have an equal distribution of the pre and post financial meltdown period as the event window.

The remainder of this study was divided in sections where section two covers literature review, section three discusses the methodology. Section four entails the discussion of findings and section five provides the conclusion and recommendations.

\section{Literature Review}

Capital markets are financial markets for the buying and selling of long-term debt or equity-backed securities. These markets channel the wealth of savers to those who can put it to long-term productive use, such as companies or governments

40 S sciendo Studia Universitatis "Vasile Goldis" Arad. Economics Series Vol 29 Issue 3/2019 ISSN: 1584-2339; (online) ISSN: $2285-3065$

Web: publicatii.uvvg.ro/index.php/studiaeconomia. Pages $38-63$ 
Nageri, K.I., Abdulkadir, R.I., (2019)

Is the nigerian stock market efficient? Pre and post 2007-2009 meltdown analysis

making long-term investments. Capital markets are defined as markets in which money is provided for periods lengthier than a year (Sullivan \& Steven, 2003).

Contemporary capital markets are practically always hosted on computer-based electronic trading systems; most can be accessed only by entities within the financial segment or the treasury divisions of governments and corporations, but some can be accessed directly by the public. There are thousands of such systems serving only small parts of the general capital markets. Bodies hosting the systems comprise the stock exchanges, investment banks, and government divisions. Physically the systems are hosted all over the world, though they incline to be focused in financial centres like London, Accra, Johannesburg, New York, Hong Kong, Lagos and Abuja (Ezike, 2002).

McLindon, (1996) identifies that a key division within the capital markets is between the primary markets and secondary markets. In primary markets, new stock or bond issues are sold to investors, frequently through underwriting. The secondary markets is where existing securities are traded among investors, typically on an exchange and over-the-counter. The presence of secondary markets intensifies the liquidity of investment in primary markets, as investors know that they are likely to be able to quickly cash out their investments if the need arises.

Efficient stock market is the market where stock prices responds very quickly to fresh (new) information, so that stock prices at any given time contains the entirety of all investors' assessments of the stock price in the market (Manasseh, 2014). For example, financial time newspaper report that a quoted company on the Nigerian Stock Exchange is to release new product or offer new service that will give it an edge against competitors. Any new investor willing to buy the stock of this company as a result of the information is too late because investors that are shrewd have bought the stock earlier and the price has already increased, it doesn't matter whether or not new product or service is finally introduced. Meanwhile, hypothesis does not postulate the continuous accuracy but signifies the totality of the available information and selections made which can be incorrect (Lo, 2005).

Theoretically, the roots of the efficient capital market hypothesis can be traced back to the work of two individuals in the 1960s: Eugene F. Fama and Paul A. Samuelson. Remarkably, they independently established the same basic concept of market efficiency from two rather different research programs. The theory states that markets make prompt amendments to stock price fluctuations. These changes in stock price arise due to the advent of new information relating to that particular stock (Nneji, 2013). A school of thought in the theory of financial econometrics that is widely accepted by financial economists is the Efficient Capital Market Hypothesis (ECMH).

In general, an asset price, denoted by $\mathrm{P}_{\mathrm{t}}$ already incorporates all pertinent information, and the only cause for the prices to change between time $t$ and time 
Nageri, K.I., Abdulkadir, R.I., (2019)

Is the nigerian stock market efficient? Pre and post 2007-2009 meltdown analysis

$\mathrm{t}+1$ will be due to shocks. The efficient capital market hypothesis therefore postulates that the assets price process follow a random walk. The random walk model without drift parameter is expressed as:

$\mathrm{P}_{\mathrm{t}}=\mathrm{P}_{\mathrm{t}-1}+\varepsilon_{\mathrm{t}}$

Where $\varepsilon_{\mathrm{t}}$ is a white noise process; $\mathrm{t}=1,2,3, \ldots \ldots \ldots, \mathrm{n}$. When $\varepsilon_{\mathrm{t}}$ is not a white noise process, the price series is said to have memory which violates the efficient capital market hypothesis (Shiriaev, 1999).

The efficient capital market hypothesis arises when the active market participants all have access to significant information, employing this information to participate rationally in order to maximise profit on their buy and sell decisions. This ultimately leads to the position where the actual price of a security is a good evaluation of the intrinsic value of that security. This implies that no stock is overprices or underpriced and as such there is no possibility of making gains by outperforming the market. The efficient market hypothesis has three forms namely: The weak form of the efficient capital market hypothesis claims that prices fully reflect the information implicit in the sequence of past prices. This version of the hypothesis implies that trend analysis and the developing of trading rules by financial analyst in predicting future stock price movement that would allow investors to earn abnormal rate of return is fruitless.

The semi-strong efficiency assumes that all publicly available information about a given security has been accurately factored into the present price of that security. Semi strong efficiency is in opposition to both fundamental and technical analysis. The semi-strong form of capital market hypothesis suggests that all publicly available information about the company's past performance as well as the prospects of the company is already reflected in the stock price. Such information includes, in addition to past prices, fundamental data on the firm's product line, quality of management, balance sheet composition, patents held, earnings forecasts, and accounting practices. Therefore, no investor can earn an abnormal return as a result publicly available information such as annual accounting reports, block trades (Fama, Fisher, Jensen, \& Roll, 1969), earnings announcements, stock split announcements, dividend announcements, and repurchase of stock announcement (Olowe, 1996, 1999; Oludoyi, 1998).

The strong form of capital market efficiency states that the current price of a stock fully reflects all existing information (both public and private) about that stock. In a strongly efficient market, no individual can out-perform the market from any information available and this can only persist to be true even if the investor is the only one with access to the information. The strong form holds that the security prices reflect all published and unpublished information. This suggests that even

42 Sciendo Studia Universitatis "Vasile Goldis" Arad. Economics Series Vol 29 Issue 3/2019 ISSN: 1584-2339; (online) ISSN: $2285-3065$

Web: publicatii.uvvg.ro/index.php/studiaeconomia. Pages $38-63$ 
Nageri, K.I., Abdulkadir, R.I., (2019)

Is the nigerian stock market efficient? Pre and post 2007-2009 meltdown analysis

the member of a company's top management staff, who is advantaged to have insider information, cannot use such information to out-perform the market.

Empirically, studies over the years have showed that concept of efficient capital market hypothesis may almost certainly be false due to various abnormalities and anomalies (Malkiel 2003; Schwert, 2002; Shiller, 2003; Gilson \& Kraakman, 2014), such anomalies include the evidence of volatility of returns on investments, data snooping (Lo \& MacKinlay, 1988, 1990), size effect (Banz, 1981 and Reinganum, 1981), the weekend effect (French, 1980), the value effect (Basu, 1977) and the momentum effect (Fama \& French, 1996) among others.

Studies have also revealed that no investor can earn an abnormal return as a result publicly available information such as annual accounting reports, block trades (Fama, Fisher, Jensen, \& Roll, 1969), earnings announcements, stock split announcements, dividend announcements, and repurchase of stock announcement (Olowe, 1996, 1999; Oludoyi, 1998).

The pioneer event study of stock splits by Fama, Fisher, Jensen and Roll (1969) have since being followed by works such as studies of events of financing decisions (Smith, 1986); corporate-control events (Jensen \& Ruback, 1983; Jensen \& Warner, 1988) others are in accounting, industrial organization, and macroeconomics (Ball, 1990; Binder, 1985; Santomero, 1991). Dividends announcement are linked with stock-price changes of the same sign (Ahrony \& Swary, 1980; Asquith \& Mullins, 1983; Charest, 1978). The reaction of stock prices to dividend announcement leads to signalling theory (Miller \& Rock, 1985) and free-cash-flow explanations (Easterbrook, 1984; Jensen, 1986) explains why increase in dividend is good news for stock prices.

Other studies to test market efficiency have used the various models such as serial correlation test, including the correlation coefficient test, Q-test, and variance ratio tests, unit root test, GARCH model variants (Gimba, 2012; Nwosa \& Oseni, 2011; Alam, Tanweer, \& Palani-Rajan, 1999; Chang \& Ting, 2000; Cheung \& Coutts, 2001; Dockery \& Vergari, 1997; Grieb \& Reyes, 1999; Lima \& Tabak, 2004; Adelegan, (2004) \& (2009); Chow, Hui, Vieito \& Zhu, 2016; Atoi, 2014; Ajibola, Prince \& Lenee, 2014; Obayagbona \& Igbinosa, 2015) among other models.

\section{Methodology}

Acceptable volatility model should appropriately models heteroscadasticity in the disturbance term and also captures the stylized fact intrinsic in stock return series such as volatility clustering, Auto-Regressive Conditional Heteroscadasticity (ARCH) effect and asymmetry (Engle, 1982). The eminent volatility models used in studies include Auto-Regressive Conditional Heteroscadasticity (ARCH) and its extensions. 
Nageri, K.I., Abdulkadir, R.I., (2019)

Is the nigerian stock market efficient? Pre and post 2007-2009 meltdown analysis

\subsection{Model Specification}

The conditional return equation was estimated using the Ordinary Least Square (OLS) regression model as follows:

$A S I_{r t}=C+\alpha A S I_{r t_{t-1}}+\varepsilon_{1 t}$

The equations 3.1 implies that the current ASI return series depends not only on previous values of $A S I_{r t}$, but also on the mean/constant $(C)$ value of $A S I_{r t}$ and the error term $\left(\varepsilon_{1 t}\right)$. The error term is tested for ARCH effect and volatility clustering and from which the conditional variance equation are derived for the ARCH models in this research.

The general form of the conditional variance, including $(p)$ lag of the residuals is as follows:

$\sigma_{t}^{2}=C+\alpha_{1} \varepsilon_{n t-1}^{2}+\ldots \ldots \ldots \ldots+\alpha_{1} \varepsilon_{n t-p}^{2}$

Equation 3.2 is what Engle (1982) referred to as the linear ARCH ( $p$ ) model because of the inclusion of the $(p)$ lags of the $\varepsilon_{n t}^{2}$ in the variance equation. Therefore an ARCH (1) model is

$\sigma_{t}^{2}=C+\alpha_{1} \varepsilon_{n t-1}^{2}$

Equation 3.3 (ARCH (1) model) indicates that the next period's return variance (from the mean equation residual) only depends on last period's squared residual (shock in the return mean equation) so a crisis that caused a large residual would not have the sort of persistence that is observed after actual crises.

Three (3) conditional distributions for the standardized residuals of returns innovations; the Gaussian distribution, student's-t distribution, and the Generalised Error Distribution (GED) are employed in the empirical analysis.

The research population is the Nigerian Stock Exchange, All Share Index return was used as the performance indicators covering the period of Jan. 2001 till Dec. 2016 divided into pre and post financial meltdown. The return series was defined as:

$A S I_{r t}=\frac{\left(A S I_{t}-A S I_{t-1}\right)}{A S I_{t-1}}$

Where $A S I_{t}$ is All Share Index at time $t$ (particular/current week in this case) and $A S I_{t-1}$ is All Share Index at time $t-1$ (current/particular week minus previous week).

\section{Analysis and Discussion}

The All Share Index (ASI) on the Nigerian Stock Exchange increased from less than 10,000 points in Jan. 2001 to the peak at over 60,000 points in March 2008 and started declining to less than 20,000 points by April 2009. The index fluctuated between 20,000 points and 30,000 points between April 2009 and Sept. 2011, then increases to more than 40,000 points in April 2009. Therefore, between the period

$44 \quad S$ sciendo Studia Universitatis "Vasile Goldis" Arad. Economics Series Vol 29 Issue 3/2019 ISSN: 1584-2339; (online) ISSN: 2285 - 3065

Web: publicatii.uvvg.ro/index.php/studiaeconomia. Pages $38-63$ 
Nageri, K.I., Abdulkadir, R.I., (2019)

Is the nigerian stock market efficient? Pre and post 2007-2009 meltdown analysis

of March 2008 and April 2009 the Nigerian Stock Exchange All Share Index was affected by the global financial meltdown of 2007-2009 as shown in figure 1 and 2 . 2001 till March 2008 while the post meltdown period is April 2009 till Dec 2016.

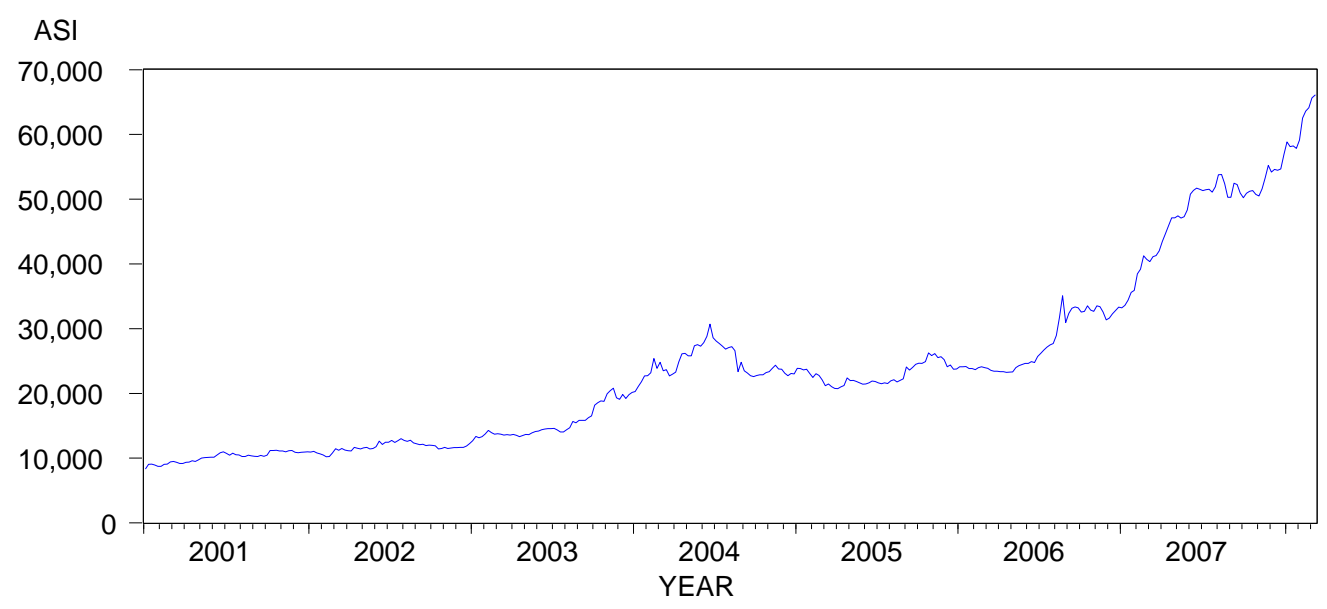

Figure 1 Weekly All Share Index on the Nigerian Stock Exchange before the Meltdown

Source: Author's computations from E-views output, 2018.

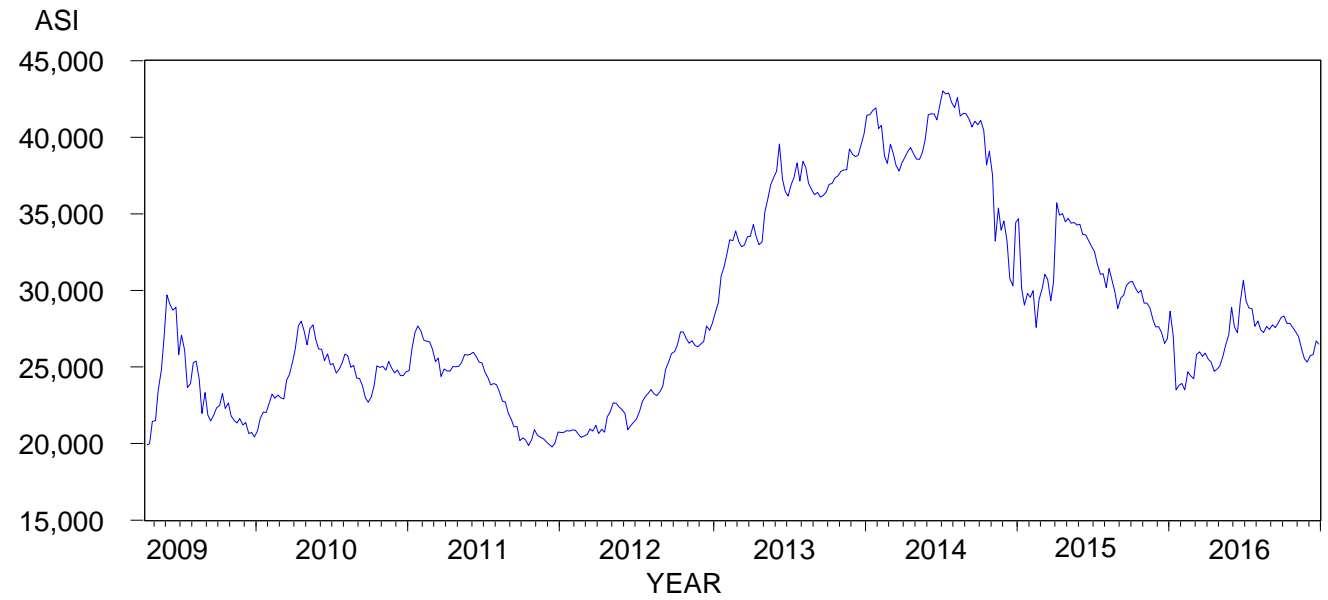

Figure 2 Weekly All Share Index on the Nigerian Stock Exchange after the Meltdown Source: Author's computations from E-views output, 2018. 
Nageri, K.I., Abdulkadir, R.I., (2019)

Is the nigerian stock market efficient? Pre and post 2007-2009 meltdown analysis

Table 1 ADF Unit Root Test Result of All Share Index Return before and after the Meltdown

\begin{tabular}{|ccc|ccc|}
\hline $\begin{array}{c}\text { ASIR before } \\
\text { meltdown }\end{array}$ & t-Statistics & P-Value & $\begin{array}{c}\text { ASIR after } \\
\text { meltdown }\end{array}$ & $\begin{array}{c}\text { Adjusted t- } \\
\text { Statistics }\end{array}$ & P-Value \\
\hline $\begin{array}{c}\text { ADF test } \\
\text { statistics }\end{array}$ & -19.35467 & 0.0000 & ADF test statistics & -18.59976 & 0.0000 \\
\hline $\begin{array}{c}\text { Critical values: } \\
1 \%\end{array}$ & -3.447580 & & Critical values: & -3.446443 \\
$5 \%$ & -2.869029 & $1 \%$ & $5 \%$ & -2.868529 \\
\\
$10 \%$ & -2.570827 & & $10 \%$ & -2.570558 \\
\hline
\end{tabular}

Source: Author's computations from E-views output, 2018.

The unit root test result of the All Share Index returns series for the pre and post meltdown period shown in table 1 revealed the P-values for the ADF test statistics is 0.0000 which shows that the null hypothesis should be rejected indicating that the return series before and after the meltdown is stationery (has no unit root).

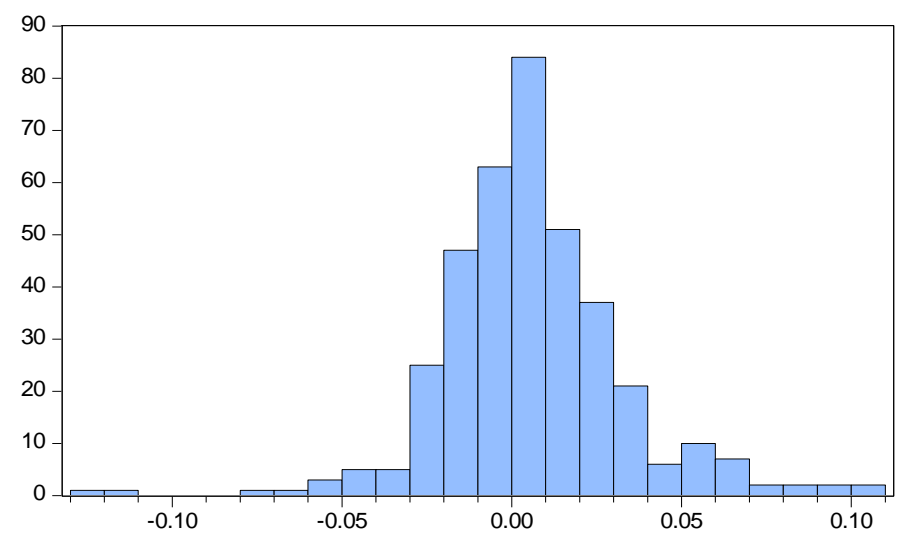

\begin{tabular}{|lr|}
\hline \multicolumn{2}{|l}{ Series: ASIRBF } \\
Sample 1/01/20013/10/2008 \\
Observations 376 \\
Mean & 0.005855 \\
Median & 0.003889 \\
Maximum & 0.105544 \\
Minimum & -0.122365 \\
Std. Dev. & 0.026989 \\
Skewness & 0.124148 \\
Kurtosis & 6.501730 \\
& \\
Jarque-Bera & 193.0723 \\
Probability & 0.000000 \\
\hline
\end{tabular}

Figure 3 Descriptive Statistics of All Share Index Return before the Meltdown Source: Author's computations from E-views output, 2018.

Figure 3 shows a positive weekly mean return and a standard deviation of $2.7 \%$. The level of price variability of return is $15.9 \%$ on the Nigerian Stock Exchange before the crisis. The skewness of 0.124148 is higher than 0 , showed that the returns before the meltdown is positively skewed. The kurtosis of 6.501730 is higher than 3 which shows that the returns before the meltdown is leptokurtic. The Jarque-Bera statistics with a value of 193.07 and a corresponding p-value of 0.0000 suggest that the null hypothesis of normal distribution should be rejected for returns before the meltdown of 2007-2009. 
Nageri, K.I., Abdulkadir, R.I., (2019)

Is the nigerian stock market efficient? Pre and post 2007-2009 meltdown analysis

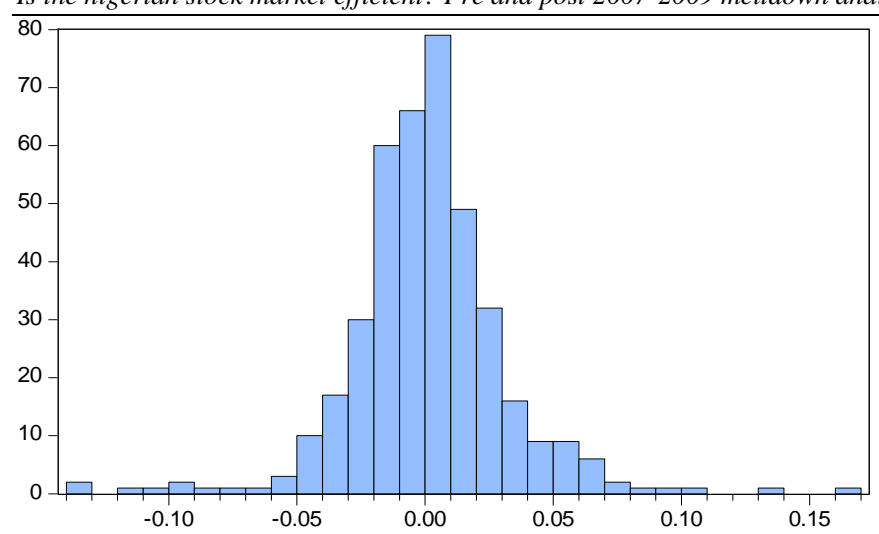

Series: ASIRAFT

Sample 4/13/2009 12/26/2016

Observations 402

Mean $\quad 0.001185$

Median $\quad 0.000870$

Maximum $\quad 0.169002$

Minimum $\quad-0.130884$

Std. Dev. $\quad 0.030878$

Skewness $\quad 0.157099$

Kurtosis $\quad 8.131351$

Jarque-Bera $\quad 442.6939$

Probability $\quad 0.000000$

Figure 4 Descriptive Statistics of All Share Index Return after the Meltdown

Source: Author's computations from E-views output, 2018.

Figure 4 shows a positive weekly mean return of 0.001185 with a standard deviation of $3.09 \%$. The level of return variability after the crisis is $22.6 \%$. The skewness is 0.157099 showing that the returns after the meltdown is positively skewed, kurtosis of 8.131351 showed that the returns on the Nigerian Stock Exchange after the meltdown is leptokurtic. The Jarque-Bera statistics value of 442.69 with p-value 0.0000 suggest that the null hypothesis of normal distribution should be rejected for the returns on the Nigerian Stock Exchange after the meltdown of 2007-2009. This results of the descriptive statistics indicates that the return series before and after the meltdown can be subjected to ARCH variant models analysis.

To achieve the objective of this study, the result of the GARCH model presented in Table 2 - 5 for whole return series, return series before the meltdown and return after the meltdown under the various distributional assumptions.

Table 2 GARCH Result for the All Share Index Return (Jan 2001 - Dec 2016)

\begin{tabular}{|c|c|c|c|c|c|c|}
\hline \multirow[t]{2}{*}{ Parameters } & \multicolumn{2}{|c|}{ Gausian Distribution } & \multicolumn{2}{|c|}{ Student's-t Distribution } & \multicolumn{2}{|c|}{ Generalised Error Distribution } \\
\hline & Estimates & P-Value & Estimates & P-Value & Estimate & P-Value \\
\hline$u$ & 0.147142 & 0.0000 & 0.121028 & 0.0010 & 0.124248 & 0.0003 \\
\hline$\omega$ & 0.000067 & 0.0000 & 0.000106 & 0.0004 & 0.000085 & 0.0004 \\
\hline$\alpha_{i}$ & 0.209177 & 0.0000 & 0.306950 & 0.0000 & 0.257695 & 0.0000 \\
\hline$\beta_{j}$ & 0.731140 & 0.0000 & 0.626216 & 0.0000 & 0.669422 & 0.0000 \\
\hline AIC & \multicolumn{2}{|c|}{-4.346110} & \multicolumn{2}{|c|}{-4.423912} & \multicolumn{2}{|c|}{-4.420061} \\
\hline $\mathrm{SC}$ & \multicolumn{2}{|c|}{-4.317776} & \multicolumn{2}{|c|}{-4.389911} & \multirow{2}{*}{\multicolumn{2}{|c|}{-4.386059}} \\
\hline HQ & \multicolumn{2}{|c|}{-4.335247} & \multicolumn{2}{|c|}{-4.410876} & -4.407025 & \\
\hline
\end{tabular}

Source: Author's computations from E-Views output, 2018. 
Nageri, K.I., Abdulkadir, R.I., (2019)

Is the nigerian stock market efficient? Pre and post 2007-2009 meltdown analysis

The result of the GARCH model in Table 2 indicates that $\mu$ as the mean of past weekly return has a positive relationship with present week return as derived from the mean equation. The P-value of the mean return is $0.0000,0.0009$ and 0.0003 under the distributional assumptions indicating that the mean past weekly return being positive, is statistically significant at $5 \%$ in predicting present return on the Nigerian Stock Exchange. The variance equation which is derived from the residual of the mean equation having $\alpha_{i}$ and $\beta_{j}$ representing the $\mathrm{ARCH}$ term and the GARCH term respectively with $\omega$ as the constant, all having positive relationship with current week All Share Index return on the Nigerian Stock Exchange.

The result indicates that the ARCH term (previous week return squared residual) and the GARCH term (previous week return variance) with $p$-values of 0.0000 for the three (3) distributional assumptions are statistically significant in predicting current week variance of return on the Nigerian Stock Exchange at 5\% significant level. The constant also shows that without the ARCH and GARCH terms, current week changes in retun will be close to zero.

This simply implies that an investor can predict current week stock return by reading past week stock return movement on the Nigerian Stock Exchange and attain better return than the market return. This indicates that the stock market is not efficient in the weak form. The Akaike Information Criterion, Schwarz Criterion and the Hannan-Quinn Criterion all have similar values with no significant difference but the student's-t distribution has the lowest criterion values which indicates that the predictive ability of the GARCH model under the student's-t distributional assumptions provide the best estimate of weekly return on the Nigerian Stock Exchange.

Table 3 GARCH Result for the All Share Index Return before the Meltdown

\begin{tabular}{|c|c|c|c|c|c|c|}
\hline \multirow{2}{*}{ Parameters } & \multicolumn{2}{|c|}{ Gausian Distribution } & \multicolumn{2}{|c|}{ Student's-t Distribution } & \multicolumn{2}{|c|}{ Generalised Error Distribution } \\
\hline & Estimates & P-Value & Estimates & P-Value & Estimat & P-Value \\
\hline$\mu$ & 0.119670 & 0.0501 & 0.089461 & 0.1168 & 0.093611 & 0.0680 \\
\hline () & 0.000476 & 0.0000 & 0.000374 & 0.0092 & 0.000372 & 0.0102 \\
\hline$\alpha_{i}$ & 0.275426 & 0.0000 & 0.362653 & 0.0239 & 0.311980 & 0.0246 \\
\hline$\beta_{j}$ & 0.040516 & 0.7936 & 0.206215 & 0.3119 & 0.170131 & 0.4821 \\
\hline AIC & \multicolumn{2}{|c|}{$\frac{1}{-4.493051}$} & \multicolumn{2}{|c|}{-4.605492} & \multicolumn{2}{|c|}{-4.602665} \\
\hline $\mathrm{SC}$ & \multicolumn{2}{|c|}{-4.440692} & \multicolumn{2}{|c|}{-4.542661} & \multicolumn{2}{|c|}{-4.539834} \\
\hline HQ & \multicolumn{2}{|c|}{-4.472264} & \multicolumn{2}{|c|}{-4.580548} & \multicolumn{2}{|c|}{-4.577721} \\
\hline
\end{tabular}

Source: Author's computations from E-views output, 2018.

The result of the GARCH model in Table 3 shows that $\mu$ as the mean of past week return before the meltdown has a positive relationship with present week return as derived from the mean equation. The P-value for the mean past weekly All Share

48 S sciendo Studia Universitatis "Vasile Goldis" Arad. Economics Series Vol 29 Issue 3/2019 ISSN: 1584-2339; (online) ISSN: 2285 - 3065

Web: publicatii.uvvg.ro/index.php/studiaeconomia. Pages $38-63$ 
Nageri, K.I., Abdulkadir, R.I., (2019)

Is the nigerian stock market efficient? Pre and post 2007-2009 meltdown analysis

Index return of $5 \%$ or more under the three (3) distributional assumptions indicates that the average past week return being positive is statistically not significant in predicting present week return on the Nigerian Stock Exchange before the meltdown at $5 \%$ level of significant. The variance equation has $\alpha_{i}$ and $\beta_{j}$ representing the $\mathrm{ARCH}$ term and the GARCH term respectively with $\omega$ as the constant, all having positive relationship with present week return on the Nigerian Stock Exchange before the meltdown.

The result indicates that the ARCH term (previous week return squared residual) with p-values of $0.0000,0.0239$ and 0.0246 under the distributional assumptions is statistically significant at 5\%. The GARCH term (previous week return variance) with p-values of $0.7936,0.3119$ and 0.4821 under the distributional assumptions is statistically insignificant in predicting current week return variance on the Nigerian Stock Exchange before the meltdown. The constant also shows that without the ARCH and GARCH terms, current changes in All Share Index will be close to zero before the meltdown.

Table 4 Wald Test Result

\begin{tabular}{|c|cc|c|c|c|c|}
\hline Test Statistics & \multicolumn{2}{|c|}{ Gausian Distribution } & \multicolumn{2}{c|}{ Student's-t Distribution } & \multicolumn{2}{c|}{ Generalised Error Distribution } \\
& Value & P-Value & Estimates & P-Value & Estimates & P-Value \\
\hline F-statistics & 8.527081 & 0.0002 & 4.433797 & 0.0125 & 3.570658 & 0.0291 \\
Chi-square & 17.05416 & 0.0002 & 8.867594 & 0.0119 & 7.141317 & 0.0281 \\
\hline
\end{tabular}

Source: Author's computations from E-views output, 2018.

The Wald test in table 4 shows the joint significant result of the ARCH and GARCH terms with the F-statistics and Chi-square values under the three distributional assumptions. The p-values of the Wald test statistics result are below $5 \%$ significant level which indicates that the ARCH and GARCH terms jointly are significant in predicting present variance in All Share Index return on the Nigerian Stock Exchange before the meltdown.

This implies that by studying the past week stock return on the Nigerian Stock Exchange, an investor can predict current week return and achieve a performance better than the market return. This shows that the market is not efficient in the weak form. The model selection criterion of Akaike Information, Schwarz and Hannan-Quinn provides comparable values but the value of the student's-t distribution is the lowest. This indicates that investors using the GARCH model under the student's-t distributional assumptions can expect the best estimate of weekly returns on the Nigeria Stock Exchange before the meltdown. 
Nageri, K.I., Abdulkadir, R.I., (2019)

Is the nigerian stock market efficient? Pre and post 2007-2009 meltdown analysis

\begin{tabular}{|c|c|c|c|c|c|c|}
\hline \multirow[t]{2}{*}{ Parameters } & \multicolumn{2}{|c|}{ Gausian Distribution } & \multicolumn{2}{|c|}{ Student's-t Distribution } & \multicolumn{2}{|c|}{ Generalised Error Distribution } \\
\hline & Estimates & P-Value & Estimates & P-Value & Estimat & P-Value \\
\hline$\mu$ & 0.194460 & 0.0005 & 0.132957 & 0.0159 & 0.140493 & 0.0090 \\
\hline$\omega$ & 0.000078 & 0.0001 & 0.000085 & 0.0081 & 0.000081 & 0.0016 \\
\hline$\alpha_{i}$ & 0.263188 & 0.0000 & 0.251813 & 0.0020 & 0.251136 & 0.0012 \\
\hline$\beta_{j}$ & 0.651247 & 0.0000 & 0.656755 & 0.0000 & 0.655032 & 0.0000 \\
\hline AIC & \multicolumn{2}{|c|}{-4.432640} & \multicolumn{2}{|c|}{-4.470225} & \multicolumn{2}{|c|}{-4.470240} \\
\hline $\mathrm{SC}$ & \multicolumn{2}{|c|}{-4.382933} & \multicolumn{2}{|c|}{-4.410577} & \multicolumn{2}{|c|}{-4.410591} \\
\hline HQ & \multicolumn{2}{|c|}{-4.412959} & \multicolumn{2}{|c|}{-4.446609} & \multicolumn{2}{|c|}{-4.446623} \\
\hline
\end{tabular}

Source: Author's computations from E-views output, 2018.

Table 5 is the result of the GARCH model of All Share Index return after the meltdown and it indicates that $\mu$ as the mean of past weekly All Share Index return has a positive relationship with present week return as derived from the mean equation. The P-value of the mean of past weekly return is $0.0005,0.0159$ and 0.0090 under the distributional assumptions. This indicates that the mean past weekly return is statistically significant at $5 \%$ in predicting present week return on the Nigerian Stock Exchange. The variance equation was derived from the residual of the mean equation with $\alpha_{i}$ and $\beta_{j}$ representing the ARCH term and the GARCH term respectively while $\omega$ is the constant. The result of the variance equation indicates that the ARCH term (previous week return squared residual) and the GARCH term (previous week return variance) with p-values of less than $5 \%$ for the three (3) distributional assumptions have positive relationship and are statistically significant in predicting current week variance of return in the Nigerian Stock Exchange after the meltdown. The constant also shows that without the $\mathrm{ARCH}$ and GARCH terms, current week changes in All Share Index will be close to zero.

This basically means that investor can determine present week share return by reviewing past week return movement on the Nigerian Stock Exchange in order to realize better return than the market return after the meltdown. This tells that the market is not efficient in the weak form. The information criterions confirm that the Generalised Error Distribution has the best predictive ability of the GARCH model to estimate weekly return of stocks in the Nigerian Stock Exchange after the meltdown. In the same vein, the Nigerian Stock Exchange was also tested for efficiency in the semi-strong form using the meltdown period as the event window. 
Nageri, K.I., Abdulkadir, R.I., (2019)

Is the nigerian stock market efficient? Pre and post 2007-2009 meltdown analysis

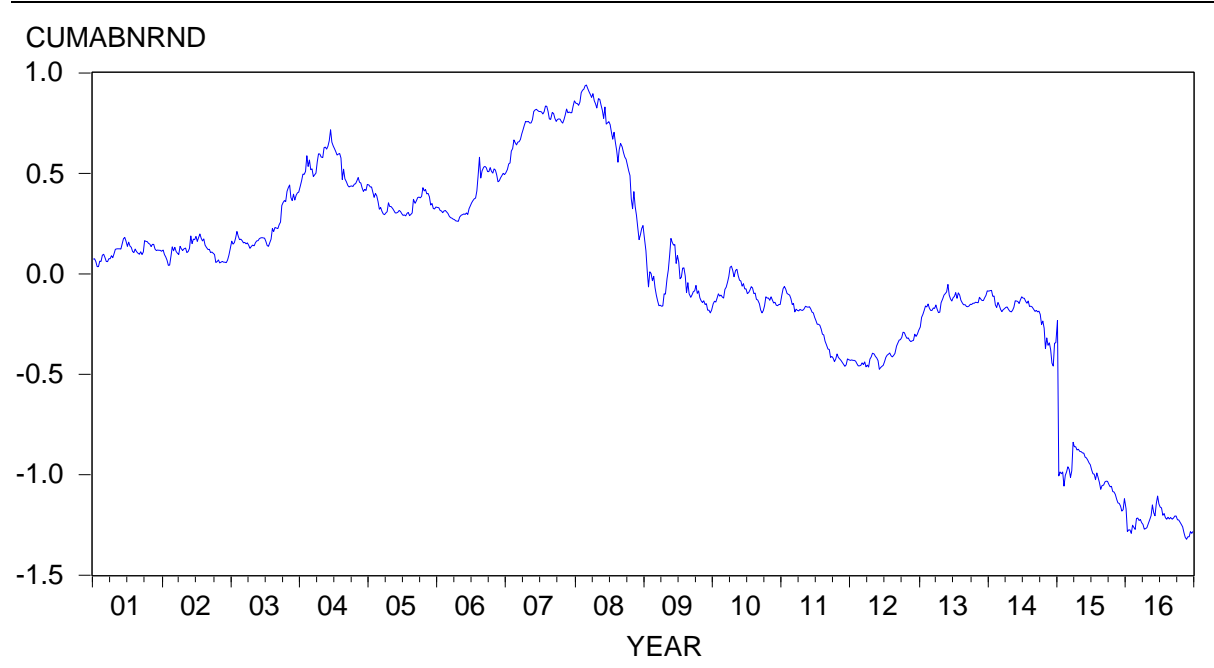

Figure 5 Cumulative Abnormal return of All Share Index Based on GARCH Model under Normal Distribution (Jan. 2001-Dec. 2016)

Source: Author's computations from E-views output, 2018.

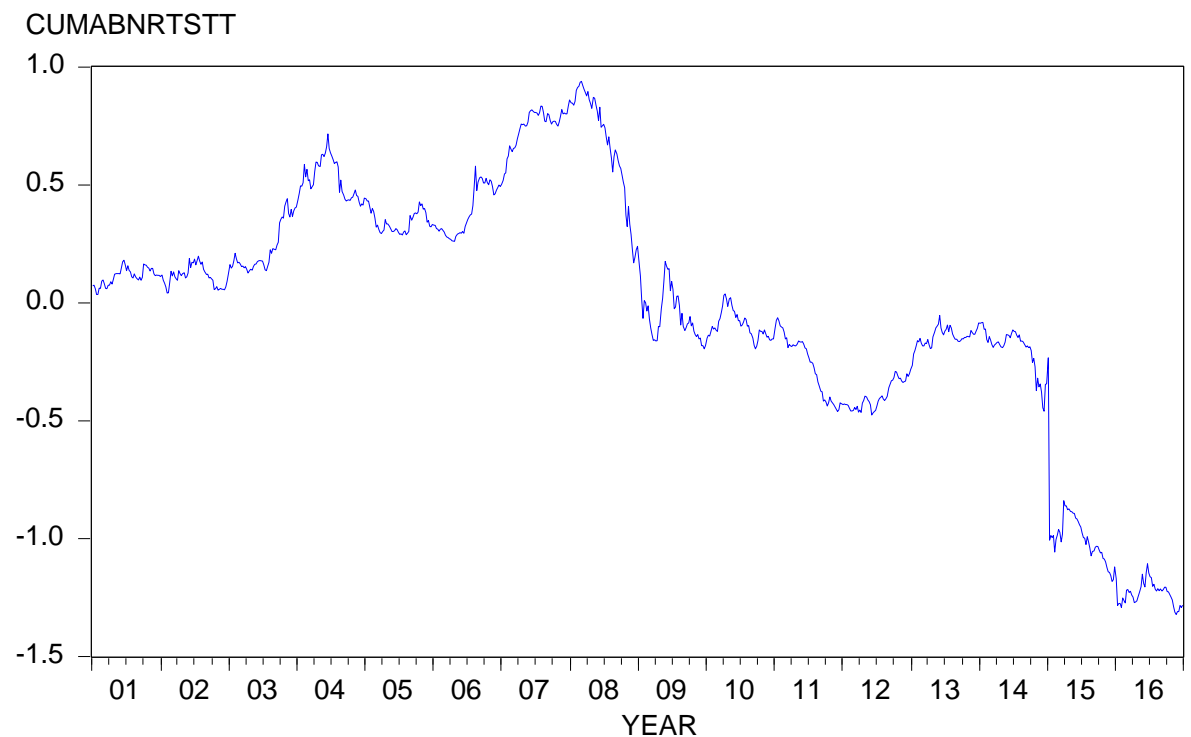

Figure 6 Cumulative Abnormal return of All Share Index Based on GARCH Model under Student's t Distribution (Jan. 2001-Dec. 2016)

Source: Author's computations from E-views output, 2018.

Studia Universitatis "Vasile Goldis" Arad. Economics Series Vol 29 Issue 3/2019 
Nageri, K.I., Abdulkadir, R.I., (2019)

Is the nigerian stock market efficient? Pre and post 2007-2009 meltdown analysis

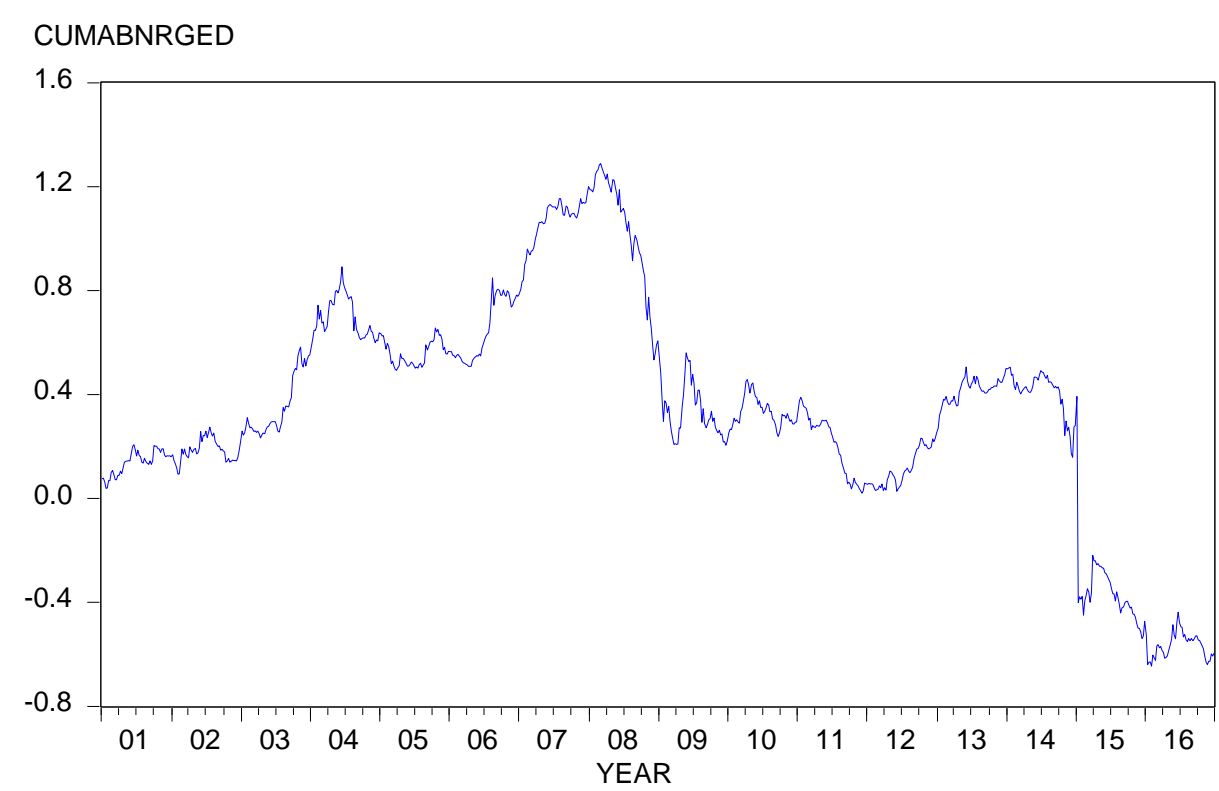

Figure 7 Cumulative Abnormal return of All Share Index Based on GARCH Model under Genaralised Error Distribution (Jan. 2001-Dec. 2016)

Source: Author's computations from E-views output, 2018.

To test if the Nigerian Stock Exchange is efficient in the in the semi-strong form, the market equation model under the three distributional assumption with their parameters were used to calculate the cumulative abnormal return under each distributional assumptions which is graphically depicted in figures 5, 6 and 7.

The cumulative abnormal returns from the three (3) distributional assumptions shows that cumulative abnormal profit on the Nigerian Stock Exchange have been increasing from zero $(0)$ to positive but during the meltdown the cumulative abnormal profit reduces and started increasing for few weeks after the meltdown. This characteristic is a sign that the Nigerian Stock Exchange is efficient in the semi-strong form. This shows that no investor can outperform the market or earn abnormal return by analysing existing relevant information or event study available in financial dailies or magazines because such information is already impounded in the current security prices.

In addition, the cumulative abnormal return from the normal distribution and student's $t$ distribution shows that cumulative abnormal return was in the positive region before the meltdown but reduced to the negative region during the meltdown and remain in the negative region since $1^{\text {st }}$ quarter 2009 (after the meltdown) till Dec. 2016. The cumulative abnormal returns from the generalized

52 Sciendo Studia Universitatis "Vasile Goldis" Arad. Economics Series Vol 29 Issue 3/2019 ISSN: 1584-2339; (online) ISSN: $2285-3065$

Web: publicatii.uvvg.ro/index.php/studiaeconomia. Pages $38-63$ 
Nageri, K.I., Abdulkadir, R.I., (2019)

Is the nigerian stock market efficient? Pre and post 2007-2009 meltdown analysis

error distribution was in the positive region before the meltdown but reduced during the meltdown and still remain slightly positive after the meltdown but got to the negative region in the early week of Jan. 2015 and remain negative till Dec. 2016.

The trend of the All Share Index as depicted in figure 1 and 2 compared to the trends of the cumulative abnormal returns under the three distributional assumptions are similar for periods before, during and after the meltdown. Meaning that the All Share index has incorporated all abnormal returns that investors can earn through new information (information about the meltdown in this case). (The values of the abnormal returns under the three (3) distributional assumptions are available on request).

In summary, the null hypothesis of weak form efficiency is not rejected while the null hypothesis of semi-strong form is rejected; therefore, the Nigerian Stock Exchange is inefficient in the weak-form before and after the meltdown of 20082009 , but was found to be semi-strong efficient. It shows that stock return on the Nigerian Stock market reflect public information relatively instantaneously due to market frictions (cost of information). The market frictions initiate a large block between when information is available and when it seemed to be fully reflected in actual prices. As a result of the level of these frictions, the Nigerian stock market returns reflect different kinds of information with greater or less relative efficiency. The ARCH effect and the serial correlation test result of the best fitted GARCH models are presented in Table 6 and 7.

Table 6 ARCH Effect Test Result of fitted GARCH Models

\begin{tabular}{|c|c|c|c|c|c|c|}
\hline \multirow[t]{3}{*}{$\begin{array}{c}\text { Test } \\
\text { Statistics }\end{array}$} & \multicolumn{2}{|c|}{ GARCH $2001-2016$} & \multicolumn{2}{|c|}{$\begin{array}{l}\text { GARCH before } \\
\text { Meltdown }\end{array}$} & \multicolumn{2}{|c|}{ GARCH after Meltdown } \\
\hline & \multicolumn{2}{|c|}{$\begin{array}{l}\text { Student's t } \\
\text { Distribution }\end{array}$} & \multicolumn{2}{|c|}{ Student's-t Distribution } & \multicolumn{2}{|c|}{$\begin{array}{c}\text { Generalised Error } \\
\text { Distribution }\end{array}$} \\
\hline & $\begin{array}{r}\text { Value } \\
\mathrm{V}\end{array}$ & P- & Value: & P- & Values & P-Value \\
\hline F-statis & 0.261879 & 0.6090 & 0.146275 & 0.7023 & 0.249154 & 0.6179 \\
\hline Observed $\mathrm{R}^{2}$ & 0.262427 & 0.6085 & 0.147004 & 0.7014 & 0.250247 & 0.6169 \\
\hline
\end{tabular}

Source: Author's computations from E-views output, 2018.

Table 6 is the ARCH effect test result of the fitted model (GARCH models) residuals used. The $p$-values of the f-statistics and the observed $\mathrm{R}^{2}$ are more than $5 \%$. Therefore, the null hypothesis of no ARCH effect is accepted. This indicates that the GARCH fitted models under the selected distributional assumptions have no ARCH effect. 
Nageri, K.I., Abdulkadir, R.I., (2019)

Is the nigerian stock market efficient? Pre and post 2007-2009 meltdown analysis

Table 7 Correlogram of Standardized Residual Square Test Results for Fitted Models

\begin{tabular}{|c|c|c|c|c|c|c|c|c|c|c|c|c|}
\hline \multicolumn{5}{|c|}{ GARCH Model 2001 - 2016} & \multicolumn{4}{|c|}{$\begin{array}{c}\text { GARCH Model before } \\
\text { meltdown } \\
\end{array}$} & \multicolumn{4}{|c|}{ GARCH Model after meltdown } \\
\hline Lag & $\mathrm{AC}$ & PAC & QStat & $\mathrm{P}$ & $\mathrm{AC}$ & PAC & QStat & $\mathrm{P}$ & $\mathrm{AC}$ & PAC & QStat & $\mathrm{P}$ \\
\hline 1 & $\begin{array}{c}- \\
0.018\end{array}$ & $\begin{array}{c}- \\
0.018\end{array}$ & 0.264 & 608 & $\begin{array}{c}- \\
0.020\end{array}$ & $\begin{array}{c}- \\
0.020\end{array}$ & & 0700 & $\begin{array}{c}- \\
0.025\end{array}$ & $\begin{array}{c}- \\
0.025\end{array}$ & 0.2527 & .615 \\
\hline 2 & 0.017 & 0.016 & 0.497 & 0.780 & $\begin{array}{c}- \\
0.020\end{array}$ & $\begin{array}{c}- \\
0.020\end{array}$ & 0.294 & 0.863 & 00 & 00 & 0.66 & 0.717 \\
\hline 3 & $\begin{array}{c}- \\
0.037\end{array}$ & $\begin{array}{c}- \\
0.036\end{array}$ & 1.628 & 0.653 & $\begin{array}{c}- \\
0.002\end{array}$ & $\begin{array}{c}- \\
0.002\end{array}$ & 0.295 & 0.961 & $\begin{array}{c}- \\
0.018\end{array}$ & $\begin{array}{c}- \\
0.016\end{array}$ & 0.7 & 0.851 \\
\hline 4 & $\begin{array}{c}- \\
0.055\end{array}$ & $\begin{array}{c}- \\
0.057\end{array}$ & 4.207 & 0.379 & $\begin{array}{c}- \\
0.016\end{array}$ & $\begin{array}{c}- \\
0.017\end{array}$ & 0.397 & 0.983 & $\begin{array}{c}- \\
0.031\end{array}$ & $\begin{array}{c}- \\
0.033\end{array}$ & 1.1897 & 0.880 \\
\hline 5 & $\begin{array}{c}- \\
0.031\end{array}$ & $\begin{array}{c}- \\
0.032\end{array}$ & 5.029 & 0.412 & 0.02 & 0.024 & 0.636 & 0.986 & $\begin{array}{c}- \\
0.028\end{array}$ & $\begin{array}{c}- \\
0.028\end{array}$ & 1.5039 & 0.913 \\
\hline 6 & $\begin{array}{c}- \\
0.052\end{array}$ & $\begin{array}{c}- \\
0.05\end{array}$ & 7.276 & 0.296 & $\begin{array}{c}- \\
0.06\end{array}$ & $\begin{array}{c}- \\
0.064\end{array}$ & 2.211 & 0.899 & $\begin{array}{c}- \\
0.027\end{array}$ & $\begin{array}{c}- \\
0.027\end{array}$ & 3 & 0.937 \\
\hline 7 & 0.083 & 0.078 & 13.04 & 0.071 & 0.12 & 0.124 & 8.237 & 0.312 & 0.102 & 0.102 & & 0.525 \\
\hline 8 & $\begin{array}{c}- \\
0.003\end{array}$ & - & 13.05 & 110 & 0.067 & 0.069 & 9.947 & 0.269 & $\begin{array}{c}- \\
0.024\end{array}$ & $\begin{array}{c}- \\
0.020\end{array}$ & & 0.606 \\
\hline 9 & 0.032 & 0 . & 3.90 & 0.126 & 0.024 & 0.033 & 10.17 & 0.337 & 0.0 & $\begin{array}{c}- \\
0.003\end{array}$ & 6.3911 & 0.700 \\
\hline 10 & 0.009 & 0009 & 13.97 & 0.175 & $\overline{-}$ & $\begin{array}{c}- \\
0.002\end{array}$ & 10.17 & 0.426 & 0.004 & 0.006 & 6.3981 & 0.781 \\
\hline 11 & $\begin{array}{c}- \\
0.05\end{array}$ & 0.04 & 16.31 & 30 & $0 . \overline{-}$ & $\begin{array}{c}- \\
0.001\end{array}$ & 19 & 0.513 & $\begin{array}{c}- \\
0.110\end{array}$ & $\begin{array}{c}- \\
0.10\end{array}$ & & 0.405 \\
\hline 12 & 0.037 & 0.04 & 17. & & 0.0 & 0.021 & & & 0.057 & 0.058 & & \\
\hline 13 & $\begin{array}{c}- \\
0.002\end{array}$ & 0.013 & 17.45 & 0.179 & 0.027 & 0.042 & 10.79 & 0.628 & $\begin{array}{c}- \\
0.040\end{array}$ & $\begin{array}{c}- \\
0.028\end{array}$ & 13.486 & 0.411 \\
\hline 14 & 0.030 & 0.02 & & & & & & & 0.061 & 0.0 & & \\
\hline 15 & 0.014 & 0.016 & 18.40 & 0.242 & 0.046 & 0.038 & 13.08 & 0.597 & $\begin{array}{c}- \\
0.001\end{array}$ & 0.004 & 15.036 & 0.449 \\
\hline 16 & 0.042 & 0.046 & 19.89 & 0.225 & 0.032 & 0.039 & 13.48 & 0.638 & 0.055 & $\begin{array}{c}- \\
0.067\end{array}$ & 16.314 & 0.431 \\
\hline 17 & 0.029 & $\begin{array}{c}- \\
0.033\end{array}$ & 20.62 & 0.244 & $\overline{-}$ & $\begin{array}{c}- \\
0.053\end{array}$ & 14.39 & 0.639 & $\begin{array}{c}- \\
0.016\end{array}$ & $\overline{-}$ & 16.422 & 0.494 \\
\hline 18 & 0.042 & $\begin{array}{c}- \\
0.027\end{array}$ & 22.11 & 0.227 & $\begin{array}{c}- \\
0.019\end{array}$ & $\begin{array}{c}- \\
0.020\end{array}$ & 14.53 & 0.694 & $\begin{array}{c}- \\
0.050\end{array}$ & $\begin{array}{c}- \\
0.023\end{array}$ & 17.478 & 0.490 \\
\hline
\end{tabular}

$\mathrm{L}, \mathrm{AC}, \mathrm{PAC}, \mathrm{Q}-\mathrm{Stat}$ and P indicate the lags, the autocorrelation function, the partial correlation function, the Ljung-Box Q-Statistic and the probability respectively.

Source: Author's computations from E-views output, 2018.

The serial correlation test result is shown in Table 4.7 under the autocorrelation function, the partial correlation function, the Ljung-Box Q-Statistic with the probabilities under lag 1 to lag 18 of the fitted models residual. The probability values from lag 1 to 18 are all more than $5 \%$ which suggests that the null hypothesis of no serial correlation is accepted. Therefore, the diagnostic tests (ARCH effect and serial correlation) result indicates that the fitted GARCH model estimates and findings are good for policy consideration, implementation and professional practice. 
Nageri, K.I., Abdulkadir, R.I., (2019)

Is the nigerian stock market efficient? Pre and post 2007-2009 meltdown analysis

Therefore, findings show that previous week return squared residual and variance with p-values of 0.0000 for the three (3) distributional assumptions are statistically significant in predicting current week variance return on the Nigerian Stock Exchange at 5\% significant level. Implying that investor can predict current week stock return by studying past week stock return movement on the Nigerian Stock Exchange and achieve a performance better than the market All Share Index return. It points to the fact that the Nigerian Stock Exchange is not efficient in the weak form before and after the meltdown. The finding corroborates the submission of Adelegan (2004), Emenike (2008), Agwuegbo, et. al (2010), Ogege and Mojekwu (2013), Afego (2012), Nwosa and Oseni (2011), Ogege and Udoka (2012), Rahman, Simon and Hossain (2016) but in contrast with Oke and Azeez (2012), Ogundina and Omah (2013), Ajao and Osayuwu (2012), and Udoka (2012). The student's $t$ distribution provides the best estimate for period before the meltdown while the generalized error distributional assumption provide the fitted estimate for the period after the meltdown.

On the other hand, test for the semi-strong form efficiency, using the abnormal and cumulative abnormal returns obtained from the three (3) distributional assumptions (using the meltdown as the event window). The cumulative abnormal return increased from zero (0) to positive but during the meltdown the cumulative abnormal profit reduces and started increasing for few weeks after the meltdown. This characteristic is a sign that the Nigerian Stock Exchange is efficient in the semi-strong form by responding to the meltdown immediately the All Share Index does.

This shows that no investor can outperform the market or earn abnormal return by analysing existing information or event study available in financial dailies or magazines because such information is already impounded in the current security prices which is supported by the findings of Manasseh (2014) Manasseh, Ozuzu and Ogbuabo (2016), Oludoyi (1998) and Mukora (2014) but in disagreement with the findings of Adelegan (2009), Eleke-Aboagye and Opoku (2013), Nneji (2013) and Osei (2002).

\section{Summary Conclusion and Recommendation}

The study evaluates the Nigerian stock market efficiency in the pre and post financial meltdown. The results of the findings revealed that the financial meltdown of 2008-2009 affected the All Share Index on the Nigerian Stock Exchange from March 2008 till April 2009.

The results of the GARCH model used indicates that investor can predict current week stock return by studying past weeks stock return movement on the Nigerian Stock Exchange and achieve a performance better than the market return before 
Nageri, K.I., Abdulkadir, R.I., (2019)

Is the nigerian stock market efficient? Pre and post 2007-2009 meltdown analysis

and after the meltdown. This shows that the market is not efficient in the weak form.

In the same vein, the market model indicates that the cumulative abnormal return on the Nigerian Stock Exchange increased from zero (before the meltdown) to positive but during the meltdown return reduced and started increasing for few weeks after the meltdown and fluctuates afterwards. This characteristic is a sign that the Nigerian Stock Exchange is efficient in the semi-strong form.

Therefore, it is concluded that, the Nigerian stock market is inefficient in the weak form during the pre and post financial meltdown of 2008-2009. However, using the meltdown as the event window, the Nigerian stock market is shown to be efficient in the semi-strong form after the financial meltdown. The findings imply that information is not immediately and freely available to all investors on the Nigerian stock market but the market act as if it were.

Based on the findings and conclusion, it is therefore recommended that publication and release of important and relevant financial information by quoted firms on the Nigerian Stock Exchange should be on-line real time. It should be made mandatory by the regulator of the market (Securities and Exchange Commission) in order to discourage rumour and speculative activities. The regulatory authority should not only spell out punishments that await violators but should be strict and firm about it. Penalty such as specific days of defaulter-suspension and subsequent delisting from the market in the event of failure to make public financial statement should be implemented. This will promote transparency, attract highly sophisticated and informed investors, improve the efficiency of the market and boost chances of cross-border listing for quoted companies on the Nigerian Stock Exchange.

\section{Acknowledgements}

The authors thank the anonymous reviewers and editor for their valuable contribution.

\section{Funding}

This research received no specific grant from any funding agency in the public, commercial, or not - for - profit sectors.

\section{Author's Contributions}

Kamaldeen Ibraheem Nageri, Ph.D. conceived the study and was responsible for the design and development of the data analysis. Kamaldeen Ibraheem Nageri, Ph.D. and Rihanat Idowu Abdulkadir, Ph.D. were responsible for data collection and analysis and also for data interpretation. Rihanat Idowu Abdulkadir, Ph.D. was responsible for the literature review section. 
Nageri, K.I., Abdulkadir, R.I., (2019)

Is the nigerian stock market efficient? Pre and post 2007-2009 meltdown analysis

\section{Disclosure Statement}

The authors have not any competing financial, professional, or personal interests from other parties.

\section{References}

1. Adelegan, O.J. (2003), Capital market efficiency and the effects of dividend announcements on share prices in Nigeria, African Development Review, 15(2-3), pp. 218-236.

2. Adelegan, O.J., (2004), How efficient is the Nigerian stock market: Further evidence, African Review of Money, Finance and Banking, 5(3), pp. 143-165.

3. Adelegan, O.J., (2009), Price reactions to dividend announcements on the Nigerian stock market, African Economic Research Consortium, Nairobi, AERC Research Paper 188.

4. Afego, P., (2012), Weak form efficiency of the Nigerian stock market: An empirical analysis (1984 - 2009), International Journal of Economics and Financial Issues. 2(3), pp. 340-347.

5. Agwuegbo, S.O.N., Adewole, A.P. \& Maduegbuna, A.N., (2010), A random walk model for stock market prices, Journal of Mathematics and Statistics, 6(3), pp. 342-346.

6. Ahrony, J. \& Swary, I., (1980), Quarterly dividend and earnings announcements and stockholders' returns: An empirical analysis, Journal of Finance, 35, pp. 1-12.

7. Ajao, M.G. \& Osayuwu, R., (2012), Testing the weak form of efficient market hypothesis in Nigerian capital market, Accounting and Finance Research, 1(1), pp. 169-179.

8. Ajibola, A., Prince, N.C., \& Lenee, T.L., (2014), Detecting market anomalies: Do evidences hold in Nigeria? International Review of Management and Business Research, 3(2), pp. 1128-1138.

9. Alam, M.I., Tanweer, H. \& Palani-Rajan, K., (1999), An application of varianceratio test to five Asian stock markets, Review of Pacific Basin Financial Markets and Policies, 2(3), pp. 301-315.

10. Arunma, O., (2010), Testimony on the global financial crisis and financial reform in Nigeria: A capital market perspective, A paper presented before the United States House of Representatives Committee on Financial Services, SubCommittee on InternationalMonetary Policy and trade.

11. Asquith, P., \& Mullins, D.W., (1983), The impact of initiating dividend payments on shareholders' wealth, Journal of Business, 56, pp. 77-96.

12. Atoi, N.V., (2014), Testing volatility in Nigeria stock market using GARCH models, CBN Journal of Applied Statistics, 5(2), pp. 65-93. 
Nageri, K.I., Abdulkadir, R.I., (2019)

Is the nigerian stock market efficient? Pre and post 2007-2009 meltdown analysis

13. Ayadi, F.O., (1984), The random walk hypothesis and the behaviour of share prices in Nigeria, The Nigerian Journal of Economic and Social Studies, 26(1), pp. 57-71.

14. Ayuba, S., (2011), The impact of the global financial market on the Nigerian stock market, (An Unpublished M.Sc. Project), Department of Economics, Ahmadu Bello University, Zaria.

15. Azeez, B.A. \& Sulaiman, L.A., (2012), Capital market efficiency: A test of the strong form in Nigeria, Australian Journal of Business and Management Research, 2(3), pp. 12-18.

16. Bailey, W., Kumar, A. \& Ng, D., (2011), Behavioral biases of mutual fund investors, Journal of Financial Economics, 102(1), pp. 1-27.

17. Baker, H.K. \& Nofsinger, J.R., (2010), Behavioral finance: Investors, corporations and markets, New Jersey: John Wiley \& Sons.

18. Ball, R., (1990), What do we know about market efficiency? Unpublished manuscript, William E. Simon Graduate School of Business Administration, University of Rochester

19. Banz, R.W., (1981), The relationship between return and market value of common stock, Journal of Financial Economics, 9(1), pp. 3-18.

20. Basu, S., (1977), The investment performance of common stocks in relation to their price to earnings ratio: A test of the efficient markets hypothesis, Journal of Finance, 32(3), pp. 663-682.

21. Binder, J.J., (1985), Measuring the effects of regulation with stock price data, Rand Journal of Economics, 16, pp. 167-182.

22. Chang, K. \& Ting, K., (2000), A variance ratio test of the random walk hypothesis for Taiwan's stock market, Applied Financial Economics, 10(5), pp. 525-532.

23. Charest, G., (1978), Dividend information, stock returns, and market efficiency-II, Journal of Financial Economics, 6, pp. 297-330.

24. Cheung, K. \& Coutts J.A., (2001), A note on weak form market efficiency in security prices: Evidence from the Hong Kong Stock Exchange, Applied Economics Letters, 8, pp. 407-410.

25. Chow, S.C., Hui, Y., Vieito, J.P. \& ZhenZhen Zhu, Z., (2016), Market liberalizations and efficiency in Latin America. Studies in Economics and Finance, 33(4), pp. 553-575.

26. Claessens, S. \& Kose, M.A., (2013), Financial crises: Explanations, types, and implications, IMF Working Paper, WP/13/28.

27. Dockery, E. \& Vergari, F., (1997), Testing the random walk hypothesis: Evidence for the Budapest Stock Exchange, Applied Economics Letters, 4, pp. 627-629.

58 Sciendo Studia Universitatis "Vasile Goldis" Arad. Economics Series Vol 29 Issue 3/2019 ISSN: 1584-2339; (online) ISSN: $2285-3065$

Web: publicatii.uvvg.ro/index.php/studiaeconomia. Pages $38-63$ 
Nageri, K.I., Abdulkadir, R.I., (2019)

Is the nigerian stock market efficient? Pre and post 2007-2009 meltdown analysis

28. Easterbrook, F.H., (1984), Two agency-cost explanations of dividends, American Economic Review, 74, pp. 650-659.

29. Ekechi, A.O., (2002), The Behaviour of stock prices on the Nigerian stock exchange: Further evidence, First Bank Quarterly Review, 1, pp. 5-16.

30. Eleke-Aboagye, P.Q. \& Opoku, E., (2013), The effect of earnings announcement on share prices in Ghana: A study of Ghana stock exchange, Research Journal of Finance and Accounting, 4(17), pp. 166-186.

31. Emenike, K.O., (2008), Efficiency across time: Evidence from the Nigerian stock exchange, Munich Personal RePEc Archive, Paper No. 22901.

32. Engle, R.F., (1982), Autoregressive conditional heteroskedasticity with estimates of the variance of United Kingdom inflation, Econometrica, 50(4), pp. 987-1007.

33. Evanoff, D.D., Kaufman, G.G. \& Malliaris, A.G., (2012), Asset price bubbles: What are the causes, consequences, and public policy options? Chicago Fed Letter, Number 304.

34. Ezike, J.E., (2002), Essentials of corporate financial management, Lagos: Jaylycent communications.

35. Fama, E.F. \& French, K.R., (1996), Multifactor explanations of asset pricing anomalies, Journal of Finance, 51(1), pp. 55-84.

36. Fama, E.F., (1965), The behaviour of stock market prices, Journal of Business, 38, pp. 34-105.

37. Fama, E.F., Fisher, I., Jensen, M. \& Roll, R., (1969), The adjustment of stock prices to new information, International Economic Review, 10(1), pp. 1-21.

38. Farhi, M. \& Cintra, M.A.M., (2009), The financial crisis and the global shadow banking system, Regulatory Review (Online).

39. Fox, J., (2009), The myth of the rational market: A history of risk, reward and delusion on wall street, New York: Harper Collins.

40. French, K.R., (1980), Stock returns and the weekend effect, Journal of Financial Economics, 8, pp. 55-69.

41. Gilson, R.J. \& Kraakman, R., (2014), Market efficiency after the financial crisis: It's still a matter of information costs, Virginia Law Review, 100, pp. 313275.

42. Gimba, V.K., (2012), Testing the weak-form efficiency market hypothesis: Evidence from Nigerian stock market, CBN Journal of Applied Statistics, 3(1), pp. 117-136.

43. Grieb, T. \& Reyes, M.G., (1999), Random walk tests for Latin American equity indexes and individual firms, Journal of Financial Research, 22(4), pp. 371-383.

44. Gust, M., (2014), Consequences and influences of the economic crisis on the efficiency of Romanian enterprises, Studia Universitatis "Vasile Goldiş" Arad Economics Series, 24(3), pp. 37-46. 
Nageri, K.I., Abdulkadir, R.I., (2019)

Is the nigerian stock market efficient? Pre and post 2007-2009 meltdown analysis

45. Inegbedion, H.E., (2009), Efficient market hypothesis and the Nigerian capital market, (Unpublished Masters Thesis), University of Benin, Nigeria.

46. Jensen, M.C. \& Ruback, R.S., (1983), The market for corporate control: The scientific evidence, Journal of Financial Economics, 11, pp. 5-50.

47. Jensen, M.C. \& Warner, J.B., (1988), The distribution of power among corporate managers, shareholders, and directors, Journal of Financial Economics, 20, pp. 3-24.

48. Jensen, M.C., (1986), The agency costs of free cash flows, corporate finance and takeovers, American Economic Review, 76, pp. 323-329.

49. Kaberuka, D., (2009), Start this engine: Africa's policymakers should prepare for global recovery by priming their private sectors, Finance and Development, 46(2), pp. 54-55.

50. Lima, E.J. \& Tabak B.M., (2004), Tests of the random walk hypothesis for equity markets: Evidence from China, Hong Kong and Singapore, Applied Economics Letters, 11, pp. 255-258.

51. Lo, A.W. \& MacKinlay, A.C., (1990), Data-snooping biases in tests of financial asset pricing models, Review of Financial Studies, 3(3), pp. 431-467.

52. Lo, A.W. \& MacKinlay, A.C., (1988), Stock market prices do not follow random walks: Evidence from a simple specification test, Review of Financial Studies, 1(1), pp. 41-66.

53. Lo, A.W., (2005), Reconciling efficient markets with behavioral finance: The adaptive markets hypothesis, The Journal of Investment Consulting, 7(2), pp. 2144.

54. Malkiel, B.G., (2003), The efficient market hypothesis and its critics, The Journal of Economic Perspectives, 17(1), pp. 59-82.

55. Manasseh, C.O., (2014), Efficient Market Hypothesis (EMH) and Nigerian capital market: An analysis of bonus issues and dividend Announcement, (Doctoral thesis, University of Nigeria, Nsukka).

56. Manasseh, C.O., Ozuzu, C.K. \& Ogbuabo, J.E., (2016), Semi strong form efficiency test of the Nigerian stock market: Evidence from event study analysis of bonus issues, International Journal of Economics and Financial Issues, 6(4), pp. 1474-1490.

57. McLindon, M.P., (1996), Privatization and capital market development: Strategies to promote economic growth, United States of America: Greenwood Publishing Group.

58. Miller, M.H. \& Rock, K., (1985), Dividend policy under asymmetric information, Journal of Finance, 40, pp. 1031-1052.

59. Mukora, M.Y.W., (2014), The effect of dividend announcement on stock returns of firms listed at the Nairobi Securities Exchange, (Masters thesis, University of Nairobi, Kenya).

60 S sciendo Studia Universitatis "Vasile Goldis" Arad. Economics Series Vol 29 Issue 3/2019 ISSN: 1584-2339; (online) ISSN: $2285-3065$

Web: publicatii.uvvg.ro/index.php/studiaeconomia. Pages $38-63$ 
Nageri, K.I., Abdulkadir, R.I., (2019)

Is the nigerian stock market efficient? Pre and post 2007-2009 meltdown analysis

60. Njiforti, P., (2015), Impact of the 2007/2008 global financial crisis on the stock market in Nigeria, CBN Journal of Applied Statistics, 6(1a), pp. 49-68.

61. Nneji, I., (2013), Efficiency of the Nigerian capital market: An empirical analysis, Research Journal of Finance and Accounting, 4(4), pp. 69-77.

62. Nwidobie, B.M., (2014), The random walk theory: An empirical test in the Nigerian capital market. Asian Economic and Financial Review, 4(12), pp. 18401848.

63. Nwidobie, B.M., (2015), Capital market efficiency: The Nigerian experience, Journal of Finance and Investment Analysis, 4(2), pp. 61-67.

64. Nwosa, P.I. \& Oseni, I.O., (2011), Efficient market hypothesis and Nigerian stock market, Research Journal of Finance and Accounting, 2(12), pp. 38-46.

65. Obayagbona, J. \& Igbinosa, S.O., (2015), Test of random walk hypothesis in the Nigerian stock market, Current Research Journal of Social Sciences, 7(2), pp. 27-36.

66. Ogege, S. \& Mojekwu, J.N., (2013), Econometric investigation of the random walk hypothesis in the Nigerian stock market, Journal of Emerging Issues in Economics, Finance and Banking, 1(5), pp. 381-400.

67. Ogege, S. \& Udoka, C.O., (2012), The efficiency of the Nigerian stock exchange: A theoretical and empirical analysis, Indian Journal of Finance, 6(9), pp. 13-20.

68. Ogundina, J.A. \& Omah, I., (2013), Test of capital market efficiency theory in the Nigerian capital market, Research Journal of Finance and Accounting, 4(1), pp. 120-123.

69. Oke, M.O. \& Azeez, B.A., (2012), A test of strong-form efficiency of the Nigerian capital market, Business Systems Review, 1(1), pp. 10-26.

70. Okpara, G.C., (2010), Analysis of the weak-form efficiency of the Nigerian stock market: Further evidence from GARCH model, The International Journal of Applied Economics and Finance, 4(2), pp. 62-66.

71. Olowe, R.A., (1996), Semi-strong information efficiency of the Nigerian stock market: Evidence from stock splits (Unpublished Doctoral Thesis), University of Lagos, Nigeria.

72. Olowe, R.A., (1999), Weak form efficiency of the Nigerian stock market: Further evidence, African Development Review, 11(1), pp. 54-68.

73. Oludoyi, S.B., (1998), Capital market efficiency and the effects of earnings announcements on share prices in Nigeria (Unpublished Doctoral Thesis), University of Ibadan, Nigeria.

74. Osakwe, P.N., (2010), The emerging-market economies in the face of the global financial crisis, in S. Dullien, D. J. Kotte, A. Márquez \& J. Priewe (Ed.), The financial and economic crisis of 2008-2009 and developing countries, pp.5372, New York and Geneva: United Nations Publication. 
Nageri, K.I., Abdulkadir, R.I., (2019)

Is the nigerian stock market efficient? Pre and post 2007-2009 meltdown analysis

75. Osazevbaru, H.O., (2014), Measuring Nigerian stock market volatility, Singaporean Journal of Business Economics, and Management Studies, 2(8), pp. 114.

76. Osei, K.A., (2002), Asset pricing and information efficiency of the Ghana stock market, African Economic Research Consortium, Paper 115.

77. Prates, D.M. \& Cintra, M.A.M., (2010), Africa and the global financial and economic crisis: Impacts, responses and opportunities, in S. Dullien, D.J. Kotte, A. Márquez \& J. Priewe (Ed.), The financial and economic crisis of 2008-2009 and developing countries, pp. 203-222, New York and Geneva: United Nations Publication.

78. Rahman, S., Simon, H.M. \& Hossain, M., (2016), An empirical analysis of weak form market efficiency: Evidence from Chittagong stock exchange (CSE) of Bangladesh, Journal of Statistics Applications \& Probability, 5(3), pp. 535-542.

79. Rapuluchukwu, E.U., (2010), The efficient market hypothesis: Realities from the Nigerian stock market, Global Journal of Finance and Management, 2(2), pp. 321-331.

80. Reinganum, M.R., (1981), Misspecification of capital asset pricing: Empirical anomalies based on earnings' yields and values, Journal Financial Economics, 9(1), pp. 19-46.

81. Samuels, J.M. \& Yacout, N., (1981), Stock exchanges in developing countries, Savings and development, 5(4), pp. 217-230.

82. Samuelson, P.A., (1965), Proof that properly anticipated prices fluctuate randomly, Industrial Management Review, 6(2), pp. 41-49.

83. Santomero, A., (1991), Money supply announcements: A retrospective, Journal of Economics and Business, 43, pp. 1-23.

84. Schwert, G.W., (2002), Anomalies in market efficiency, The Bradley Policy Research Center.

85. Shefrin, H., (2007), Behavioral finance: biases, mean-variance returns, and risk premiums, CFA Institute Conference Proceedings, 24(2), pp. 4-12.

86. Shiller, R.J., (2000), Irrational exuberance, New Jersey: Princeton University Press.

87. Simon, H., (1957), A behavioral model of rational choice, in models of man, social and rational: Mathematical essays on rational human behavior in a social setting, New York: John Wiley \& Sons.

88. Smith, C.W. Jr., (1986), Investment banking and the capital acquisition process, Journal of Financial Economics, 15, pp. 3-29.

89. Sullivan, A. \& Steven, M.S., (2003), Economics: Principles in action, Upper Saddle River: Pearson Prentice Hall.

90. Thaler, R.H., (1993), Advances in behavioral finance, New York: Russell Sage Foundation.

62 Sciendo Studia Universitatis "Vasile Goldis" Arad. Economics Series Vol 29 Issue 3/2019 ISSN: 1584-2339; (online) ISSN: $2285-3065$

Web: publicatii.uvvg.ro/index.php/studiaeconomia. Pages $38-63$ 
Nageri, K.I., Abdulkadir, R.I., (2019)

Is the nigerian stock market efficient? Pre and post 2007-2009 meltdown analysis

91. Thaler, R.H., (2005), Advances in behavioral finance, volume II (Roundtable series in behavioral economics), Princeton: Princeton University Press.

92. Udoka, C.O., (2012), Weak-form market efficiency: Dynamic effects of information on the Nigerian stock market, Interdisciplinary Journal of Contemporary Research in Business, 4(7), pp. 417-429.

93. Ujunwa, A., Salami, O.P. \& Umar, H.A., (2011), The global financial crisis: Realities and implications for the Nigerian capital market, American Journal of Social and Management Sciences, 2(3), pp. 341-347.

94. Vitali, F. \& Mollah, S., (2010), Stock market efficiency in Africa: Evidence from random walk hypothesis, Mid-West Finance Association Annual Meeting, West Chicago River North.

95. Yadirichukwu, E. \& Ogochukwu, O.B., (2014), Evaluation of the weak form of efficient market hypothesis: Empirical evidence from Nigeria, International Journal of Development and Sustainability, 3(5), pp. 1199-1244. 